\title{
REMEMBERING THE RIVER DAUGAVA: THE ECONOMICS AND ETHICS OF HYDROELECTRIC DAMS
}

\author{
Gunars Brazma ${ }^{1}$, Dr. phil., \\ ${ }^{1}$ Latvia University of Life Sciences and Technologies
}

\begin{abstract}
Hydroelectric dams built on the largest river of Latvia - the Daugava, are essential for energy supply of Latvia. The largest of them - Plavinas hydroelectric plant, was built during the period of the Soviet rule and is still one of the largest in Europe. As a result, the valley of the river Daugava with its unique landscapes and cultural values was flooded, despite the objections by a significant part of Latvian people. Two decades later the construction of another - Daugavpils hydroelectric dam -, was suspended because of similar protests. The debates about the effects of hydroelectric dams are continuing since Latvia regained independence in 1991 . The aim of this paper is to assess these debates in the context of environmental ethics.

According to approach of environmental economics, the main method for the assessment of environmental projects is the cost/benefit analysis. Likewise, the critics of construction of dams apply predictable economic costs as an argument against the construction, for instance, pointing to damages to fishery. However, economic costs were not the main reason for the protests. The main reason was the expected irreversible losses of natural and cultural values that were assessed as "priceless". Such attitude of a large part of society suggests that "non-economic" values have to be taken into account in comprehensive assessment of these projects. The significance of these values has to be recognized, and the results of cost/benefit analysis should not be a single criterion used in the assessment of the projects of hydroelectric dams.
\end{abstract}

Key words: hydroelectric power, cost/benefit analysis, environmental values, non-economic values.

JEL code: $A 12, A 13, Q 51$

\section{Introduction}

The debates about the hydroelectric dams on the river Daugava are going on for more than a half of century and the construction of dams still has both defenders and critics. Both sides propose their arguments, but there is a lack of comparative and comprehensive assessment of the arguments from the ethical point of view. Ethics as the branch of philosophy is not empirical but normative - it deals with value judgments implicit in such debates. The aim of this paper is to assess proposed arguments in the context of environmental ethics, applying a case-study approach. This method of applied ethics works from the "bottom up", starting with our responses to concrete cases and then proceeding to the development of more abstract principles (Arras, 2001). In this case, our first task will be reviewing historical context in which the debates about the hydroelectric dams in Latvia have been developing. The next task of the research will be comparative consideration of the arguments proposed by both critics and defenders of the construction of dams. Then these arguments will be assessed in the light of the principles of cost/benefit analysis - the main method used in contemporary environmental economics. Finally, we will consider the problem of applying economic cost/benefit analysis to a large scale environmental projects that include irreversible environmental damages. Comprehensive assessment of such damages must take into account possible relevance of "non-economic", for example, aesthetic or cultural values that cannot be measured in monetary terms. These values are often mentioned by the critics of dams' construction. The general arguments for the relevance of various "non-economic" values will be presented. Therefore, in addition to economic cost/benefit analysis, "non-economic" values must be taken into account also in the assessment of large scale environmental projects, including the construction of hydroelectric dams. 


\section{Research results and discussion 1. Historical context}

The river Daugava is essential in Latvian geography, history and economy. Historically, the Daugava has been significant for transport (particularly for timber) and fishery. In 1930's the Times correspondent described the Daugava as "the river of salmon and lampreys" with beautiful rocky banks in the central part of Latvia (Urch, R.O.G., 1938). However, since then the landscapes around Daugava and its role in the economy has changed significantly as the result of construction of dams for hydroelectric power plants.

In order to understand the decisions about construction of these dams, the context of political and social history of Latvia must be taken into account, as broadly outlined in the paper (and in the related documents) of historian Martins Mintaurs (Mintaurs, M., 2013). The summary of historical context given here is based on this paper.

The earliest ideas to use the river Daugava for producing electric power were proposed before the First World War when Latvia was a part of Russian empire. Suggestions about the construction of several hydroelectric plants were also discussed after Latvia became independent in 1918. As a result, during the thirties the first - Kegums hydroelectric plant - was constructed. It is currently producing $261 \mathrm{MW}$ of power (Strikis V., 2012, 322).

After Latvia was occupied by the USSR in 1940, new plans for construction of hydroelectric plants emerged. They were facilitated by the perception of large hydroelectric cascades as the symbol of Soviet state power. In 1955, it was decided to construct hydroelectric plant designed by Moscow engineers in Aizkraukle district with planned power 600 MW (according to other calculations $300 \mathrm{MW}$ ). The planned plant was named Plavinas hydroelectric power station.

Unusually for the USSR of that time in Latvia, the plans of new plant caused public debate, in parts even published in mass media. In March of 1958, the petition signed by more than fifty members of intelligentsia (writers, artists, scientists etc.) was submitted to the government of Latvian SSR (Soviet Socialist Republic). The protest was provoked by the fact that the beautiful landscapes and historical sites of the Daugava's valley would be flooded as a result of plant's construction.

On the other hand, the leadership of Communist Party of Latvia could allude to "tens of Latvian engineers" that support the project drafted in Moscow. The ideological mood of Soviet period also should be taken into account - enthusiasm about economical and scientific-technological progress in the part of society could be genuine. Moreover, the existence of sufficient supply of electric power was not seen as something self-evident, as it is nowadays.

Crucial turning point for the decision to start the construction of Plavinas hydroelectric plant was the removal from power of the so-called Latvian "national communists" in 1959. New government of Latvian SSR started the politics of russification and promoting immigration from other parts of the USSR in order to supply the workers for new industrial enterprises. For this reason additional electric power was needed.

The construction of Plavinas hydroelectric plant begun in 1960. Relocation of burials, cutting the trees, dismantling and even blowing up buildings including an Orthodox Church, was carried out before the creation of water reservoir. The valley of the Daugava obtained "Moon's landscape", which was flooded in $1965-1966$.

During the seventies another - Riga hydroelectric plant was built on the Daugava, currently producing 402 MW of power (Strikis V., 2012, 322). The project to complete the intended cascade 
of dams - to build the Daugavpils hydroelectric plant was launched during the same decade. However, historical context has changed. During the second half of the eighties - the years of "perestroika", public opinion in Latvia became more daring to express negative attitude to possible flooding of another segment of Daugava valley. Protests that started in the autumn of 1986 with the newspaper article by two journalists - Dainis Ivans and Arturs Snips, grew into wider movement - more than 34000 people signed letters against this project (Zirnis E., 2017). Preparatory works of the project were suspended, and in the autumn of 1987 the government of the USSR stopped the project. The protests against the construction of Daugavpils hydroelectric dam were one of first actions of Latvian people that eventually lead to regaining of independent Latvian state in 1990-1991.

\section{Arguments then and now}

How to assess the decision to construct Plavinas hydroelectric plant, looking back over a time span of more than a half of century?

Discussing such as question now may seem meaningless, not the least because it was built during the years of the Soviet occupation when deciding such issues was not done democratically. Nowadays a proposal to construct this dam almost certainly would be regarded as unacceptable for the large majority of Latvian society. However, in general, opinions about construction of hydroelectric plants on the Daugava never have been totally negative. The first of them - Kegums hydroelectric plant was built during the years of Latvian independence. It is possible that even if Latvian independence was preserved after the Second World War, discussions about construction of new hydroelectric plants had continued.

There is also no unanimity of views concerning this issue nowadays. Positive aspects of hydroelectric plants are often mentioned by economists and engineers. About a half of electric power in Latvia nowadays is produced by hydroelectric plants; Plavinas hydroelectric plant with its present power 868 MW (Strikis V., 2012, 322) produce about $25 \%$. In addition, this is significant in the context of such important geo-political aspect as promoting independence from Russian energy supplies. Moreover, from global perspective, hydro-energy is one of the greenest ways of renewable energy production, which has comparatively low costs and does not produce emissions into atmosphere. Once rejected project of Daugavpils hydroelectric plant is now being defended (Strikis V., 2012, 322). According to one opinion reported in mass media, nowadays modern technologies (for instance, horizontal turbines) could create hydro-energy with lower rising of water level than in the original project.

Thus, the debates about construction of hydroelectric plants have not lost their relevance. How to assess an arguments for and against construction of hydroelectric dams that had been mentioned before the construction of Plavinas hydroelectric plant and the arguments that are mentioned now?

In the aforementioned petition of 1958 against Plavinas hydroelectric plant it is emphasized that territory planned to flood according to this project is "the most beautiful place in Latvia", and it is "extremely important, that the project of hydroelectric plant must be such that the creation of water reservoir would require the least possible sacrifices from other branches of economy, as well as from preservation of cultural sites and people's national traditions" (Mintaurs M., 2013, 91). In the petition these expected losses were characterized as "priceless". 
The authors of the petition did not deny the necessity of new hydroelectric plant, but their hopes were related to alternative project of so-called derivation hydroelectric plant - the construction of a dam on artificial bypass canal with the length of $45-50 \mathrm{~km}$. There is the admission in the petition that without this alternative, the question indeed would arise, that "even the greatest natural beauty and the most valuable cultural monuments must be sacrificed for people's bright future" (Mintaurs, M., 2013, 92). Concerning the last formulation, it could be added that quasi-religious language of "sacrifice" sometimes also appears in remarks of the defenders of Plavinas hydroelectric plant - as formulation that natural beauty had been "sacrificed" (though usually without mentioning of any higher value for the sake of what this sacrifice was carried out).

According to calculations mentioned in the petition, the derivation project would be only a little more expensive (2098.0 million roubles) in comparison to total predictable costs of Plavinas' and another possibly constructed next to Plavinas plant - Jekabpils hydroelectric plant (1932.2 million roubles), but its power - a little smaller (respectively $254 \mathrm{MW}$ un $310 \mathrm{MW}$ ). However, it should be noted that according to calculations of other Latvia's engineers the costs of the derivation project would be considerably higher, and its effectiveness - essentially lower (Mintaurs M., 2013, 60, 72). Besides, an area or flooded territories would be larger. The deficiencies of derivation project were also admitted by its defenders.

Economic arguments against the construction of Plavinas dam were also mentioned in the petition and other publications, for instance, concerning predictable losses to fishery, to the production of dolomite, and to the development of tourism. This leaves an impression that although the essential reason for protests against planned dam was "priceless" losses of natural and cultural values, it appeared important to the authors of protests to add to their criticisms the arguments concerning the expected economic damages.

Similar approach was used in 1986-1987 during the protests against the project of Daugavpils hydroelectric dam, and in recent publications about this issue. For instance, in a recent interview Dainis Ivans claimed: "Leading hydro-engineers have told me that nowadays nobody would construct Plavinas hydroelectric plant ... firstly, because of abnormally high costs, and, secondly, it would not be permitted by the demands of the preservation of nature and of economy of natural resources. If the Daugava had remained the richest European salmon river as it was before the construction of Plavinas dam, today for sold salmon every year, we could buy more electric power than produced by all three hydroelectric plants together" (Zirnis E., 2017, 13).

Thus, critics usually mention two kinds of arguments against hydroelectric dams - economic and non-economic (based on "priceless" losses), and try to demonstrate that both kinds of arguments lead to conclusion against these projects.

According to economic arguments, all predictable benefits and costs resulting from hydroelectric plant construction must be compared. Possibly, the critics of these projects can hope that such comparisons would be sufficient to reject the dams' construction. However, it is difficult to predict results of such calculations beforehand. Concerning possible construction of Daugavpils dam, during the debate in 1986, after preliminary works already had begun, one of engineers supporting the project, suggested: "How to proceed now? We, members of power industry, could try to calculate in roubles what are the advantages of construction of Daugavpils hydroelectric plant, but you, who are against, make an effort to calculate [the disadvantages], and in the same roubles" (Ivans D., Snips A., 1989, 55). 
This suggestion, if referred to in the context of market economy, reminds of cost/benefit analysis used in the contemporary environmental economics. Its basic idea appears to be consistent with the principles of rational decision making - to compare all expected costs and benefits of a project with alternatives (including the rejection of the project) and to act in accordance of the results of this analysis. However, cost/benefit analysis is based on a questionable assumption that all costs and benefits can be calculated in monetary values. How to calculate the monetary value of the benefits of preserving the landscape because it is regarded as "the most beautiful place in Latvia"?

Defenders of cost/benefit analysis in these cases try to find a way to express in monetary values the equivalent of benefits of preserving natural environment which could be compared to costs of lost economic opportunities. Various methodologies have been proposed. In the assessment of environmental projects contingent valuation method is the most widely used (Hanley, Brabier, $2009,45)$. It is based on polls on how much people would be willing to pay for, for instance, preservation of a beautiful landscape, or, how large monetary compensation they would be ready to accept for the loss of this landscape. For instance, the question could be asked: how much I would be willing to pay additionally for electricity (and for other goods prices of which depend on the price of electricity), if the plant is not constructed?

Willingness to pay for preserving natural environment can be related not only to economic opportunities (for instance, concerning fishery or tourism), but also to so-called "existence values". These are values that an individual may attach to natural values (beautiful landscapes, rare species etc.) even if he or she never plan to travel to these places and never will be in any direct contact with them. It is quite possible that some Latvians would be willing to pay, for instance, for preservation of Indian tigers in their natural habitat, even they do not intend to travel to India. If so, this means that there are individuals that are willing to pay for the awareness that tigers as rare species exist and need to be preserved for future generations. However, in the context of environmental economics, these "existence" values also belong to economic values because they are assessed as willingness to pay.

Detailed cost/benefit analysis is a complex and expensive activity, which is full of various technical and methodological difficulties as described in environmental economics' publications (Hanley N., Barbier, E.B., 2009; Smith S., 2011; Nikodemus, O., Brumelis, G., 2015). However, in addition to specific methodological problems, there is a more conceptual problem: are empirical (descriptive) research on willingness to pay, sufficient for ethical (normative) conclusions about the proposed actions leading to changes in the natural environment? Is it appropriate or even possible to measure all values in monetary terms?

\section{Do "non-economic" values exist?}

There is at least a theoretical possibility that calculations of cost/benefit analysis applied to the construction of Plavinas (or Daugavpils) hydroelectric plant demonstrate that economic benefits of preserving natural environment are lower than costs of lost economic opportunities resulting from a refusal to construct the plant.

In this case remaining argumentation for persistent critics of construction would be not be based on cost/benefit analysis, but rather on the premise that there are costs of dam construction which are in principle "priceless", so it is wrong to construct a dam even if economic benefits of construction were higher than costs. Evidently, most critics of Plavinas (or Daugavpils) dams' 
construction proceed in this way. "Non-economic" values are genuine reason for protests, and the economic reasons are mentioned mainly as additional.

Which approach is more justified - based on economic cost/benefit analysis or based on "non-economic" values? Do "non-economic" values - values that in principle cannot be measured in monetary terms - exist?

There is the debate in environmental ethics between defenders of anthropocentric approach who claim that reasoning about environmental values is meaningful solely from human (including future generations) perspective, and defenders of other (bio-centric, holistic etc.) approaches who claim that living nature also has an intrinsic value. However, in order not to extend this discussion too far, let us only look from anthropocentric perspective.

In the context of market economy, the idea of "non-economic" values may seem meaningless in a principle. A value of any goods of services is identical with a price that a consumer is willing to pay for them. As economist Thomas Sowell explains, all values are "non-economic" (Sowell T., 2011, 591). The task of economics is to explore conditions how these "non-economic" values are created and distributed in the most efficient way. Efficiency is promoted by market, which also compares these values by exchange. Thus, it could be said that all values are also economic - the economic value appears in equivalent exhange. Sowell adds that in economics it is not meaningful to reason about objective or "true" values; economic values are solely subjective. Otherwise it would not be possible even to explain an exchange by selling and buying. For example, if I buy a newspaper for 50 cents, subjectively I evaluate obtained newspaper as more valuable than 50 cents, but a seller, on the contrary, evaluates obtained 50 cents as more valuable than a sold newspaper. It would be meaningless to ask for objective or "true" value of this newspaper (Sowell T., 2011, 37).

However, if we are looking beyond the economic sphere of selling and buying, do other kinds of values exist in addition to economic values? Various reasons can be mentioned in favour of this conjecture. There are values that are expressed by perceiving an object not as goods for use or sale, but in other ways, for instance, respect, or admiration of aesthetic value. To emphasize such an attitude, this kind of value can be characterized as "not for sale".

To reality of this kind of "non-economic" values also points a widespread intuition that there are values whose equalizing with price explicable in monetary terms would mean diminishing this value (Kelman S., 2012, 355). One of the spheres where such values exist is personal relationships, for example, friendship (Anderson E., 1993). In this sphere, exchanges are based on gift giving, but an exchange based on selling and buying would degrade these relationships. It is not possible to buy true friendship (as opposite to something that merely resembles friendship). Even the most radical defender of market economy would not deny this. Also, there are professions (for instance, the profession of a physician) in which internal ethical standards of excellence are introduced in order to preserve their integrity and professional values from degradation that could arise from too much dependence from profit considerations.

Values of natural environment in many cases can be viewed as a kind of "non-economic" values. They also can be regarded as "not for sale" in order to preserve them from diminishing. For instance, when asked the question, what monetary compensation a person would be willing to accept for a damaged scenery in natural monuments of the South-west of the USA (for example, the Grand Canyon) resulting from a construction of an electric power plant, more than a half of respondents replied that "infinite" compensation would be required, or refused to answer the 
question, regarding it as an attempt to bribe (Anderson E., 1993, 209). So, an attitude to "non-economic" values can exhibit itself as non-willingness to pay.

Another feature of "non-economic" values is that society may accept legal restrictions for their preservation. For instance, it is prohibited to sell oneself to slavery, even if somebody is willing to do this; similar restrictions are legally introduced in respect of selling bodily parts or organs. The existence of such restrictions in liberal democratic states can be justified because of admitting that in the moments of difficulties and vulnerability, a person could submit into temptation to sell his freedom or bodily integrity, thus diminishing their value. However, the same persons are not only individual customers or entrepreneurs, but also citizens (Sagoff M., 2008). As citizens they can admit such values as common good, and support legal norms for their preservation. Attitude to natural values can be justified in a similar way.

\section{Pluralistic approach to values}

Acknowledging the significance of "non-economic" values raises a question: how to compare these values with economic ones? In context of the case described above, it could be asked which values are more significant in assessment of projects related to changing the natural environment?

This way of formulating a question is based on assumption that it is possible to find some common scale of measuring both types of values. However, this seem lead to unsurmountable difficulties. For instance, the attempt to base them on individual's existing preferences ignores the option that environmental (and other) values can have "transformative power" - an individual can start to assess these values only after he or she has been introduced to them. There is a possibility of opposite process as well - people become so accustomed with a loss of a value that they stop appreciating it.

These difficulties can be solved by admitting that qualitatively different kinds of values exist, which can be incommensurable on any common scale, thus also incommensurable with one another. This is the approach of value pluralism. It is commonly agreed that there are different criteria of value in different spheres of life. We do not assess on the same scale, for example, scientific theories and works of art. Similarly, aesthetic values are not more or less significant in comparison to economic values; they are qualitatively different.

This conclusion does not mean denying that economic cost/benefit analysis has an important role in assessing environmental projects. Cost/benefit analysis is a valuable method for comprehensive assessment of the environmental impacts of different projects. However, this method should also be applied with caution (Hansson S., 2007; Hwang K., 2016). Even if the economic benefits of a project surpass the costs, the cost/benefit analysis cannot be regarded as final judgment, but as one of the factors informing public discussion (Schmidtz, D., 2012).

The admission of value pluralism underlines the possibility of potentially difficult choices and moral dilemmas. On the one hand, it cannot be ruled out that considerable economic benefits are preferred to some losses of non-economical values. But, on the other hand, it cannot be ruled out that for the sake of preserving of significant non-economic values society may decide not to realize a project whose economic benefits exceed costs. It seems that large majority of people who are against the construction of Plavinas and Daugavpils hydroelectric dams, share this opinion. The question then arises - why do they nevertheless use additional economic arguments in support of their opinions? The most likely explanation is the fear that otherwise the attitude would be 
characterized as "merely emotional". However, people's intuitions concerning values can be based on more comprehensive understanding of the issues than any preconceived economic approach.

It can be objected that admitting the role of "non-economic" values in decision making suggests replacing the cost/benefit analysis, which at least strives to objective and quantitative evaluation of the situation, with much less objective decision making. The non-economic arguments may indeed be vague, but it follows from the observation that in the presence of value pluralism, a monistic value scale is impossible. According to comment ascribed to John Maynard Keynes: "I would rather be vaguely right than precisely wrong" (cited in Aldred J., 2010, 177).

\section{Conclusions, proposals, recommendations}

The above described analysis applied to the case of building dams for hydroelectric plants on the river Daugava leads to the following conclusions.

1) The debates about the construction of large scale hydroelectric plants in Latvia such as Plavinas and Daugavpils plants, reveal that the main reason for objections against these projects was the irreversible loss of "priceless" environmental values.

2) It would be wrong to assess this widespread opinion as merely emotional attitude unjustified rationally. This attitude can be justified by comprehensive consideration of relevant values and admitting the significance of "non-economic" values that cannot be expressed in monetary terms.

3) Therefore, in addition to economic cost/benefit analysis, the role of "non-economic" values should be taken into account in assessment of environmental projects, and in particular to the dams' construction on Daugava.

4) More generally, when large and irreversible losses of "non-economical" environmental values are at stake, it is justified to consider abandoning a project even if its economic benefits are higher than costs.

\section{Bibliography}

1. Aldred, J. (2010). The Sceptical Economist. Revealing Ethics Inside Economics. Routledge.

2. Anderson, E. (1993). Value in Ethics and Economics. Cambridge, Massachusetts \& London, England: Harvard University Press.

3. Arras, J. (2001). A Case Approach. In: "A Companion to Bioethics". Ed. by Kuhse, H. and Singer, P. Blackwell Publishers, pp. 106-114.

4. Hanley, N., Barbier, E.B. (2009). Pricing Nature. Cost-Benefit Analysis and Environmental Policy. Cheltenham, UK, Northampton, MA, USA.

5. Hansson, S. (2007). Philosophical Problems in Cost-Benefit Analysis. Economics and Philosophy 23(02), pp. 163-183. Retrieved: https://www.researchgate.net/publication/227390985_Philosophical_problems_in_cost-benefit_analysis Access: 23.01. 2018.

6. Hwang, K. (2016). Cost-Benefit Analysis: its Usage and Critiques. Journal of Public Affairs. Vol. 16 Number 1, pp. 75-80. Retriewed: http://onlinelibrary.wiley.com/doi/10.1002/pa.1565/abstract Access: 23.01.2018.

7. Ivans, D., Snips, A., sast. (1989). Domu Daugava. Sirdsdaugava ("Daugava of Thoughts. Daugava of Heart"). Riga, Avots.

8. Kelman, S. (2012). Cost-Benefit Analysis. An Ethical Critique. In: "Environmental Ethics: What Really Matters, What Really Works". Ed. by Sshmidtz, D. and Willott, E. New York, Oxford: Oxford University Press, pp. 350-357.

9. Mintaurs, M. (2013). Ieskats Plavinu hidroelektrostacijas tapsanas vesture (Introduction in Building of Plavinas' Hydroelectric Power Station). In: Atminu Daugava ("The Daugava of Memories"). Biedriba "Koknesei", pp. 50-105.

10. Nikodemus, O., Brumelis, G. (2015). Dabas aizsardziba ("Protection of Nature"). Riga: LU Akademiskais apgads.

11.Sagoff, M. (2008). The Economy of Earth. Philosophy, Law, and the Environment. Second edition. Cambridge University Press.

12. Sowell, T. (2011). Basic Economics. A Common Sense Guide to Economy. Fourth Edition. Basic Books. 
13. Schmidtz, D. (2012). A Place for Cost-Benefit Analysis. In: "Environmental Ethics: What Really Matters, What Really Works". Ed. by Sshmidtz, D. and Willott, E. New York, Oxford: Oxford University Press, pp. 387-400.

14. Smith, S. (2011). Environmental Economics: A Very Short Introduction. Oxford: Oxford University Press.

15. Strikis, V. (2012). Energijas razosanas ekonomiskais izdevigums no atjaunojamiem energoresursiem (Economic Eficciency of Energy Production from Renewable Sources). In: Atjaunojama energija un tās efektiva izmantosana Latvija ("Renewable Energy and its Effective Use in Latvia"). Jelgava, LLU, pp. 315354.

16. Urch, R.O.G. (1938). Latvia. Country and People. London: George Allen \& Unwin LTD.

17. Zirnis E. (2017). Staburags augsamcelas muzeja ("The Resurrection of Staburags in a Museum"). Sestdiena, 2017, 22. September, pp. 11.-15. 